\title{
Circulating Tumor Nucleic Acids: Perspective in Breast Cancer
}

\author{
Ida Casciano Angela Di Vinci Barbara Banelli Claudio Brigati Alessandra Forlani \\ Giorgio Allemanni Massimo Romani
}

Laboratory of Tumor Genetics, Istituto Nazionale per la Ricerca sul Cancro - IST Genova, Italy

\author{
Key Words \\ Breast cancer - Biomarker - Molecular biology . \\ Circulating nucleic acids
}

\section{Summary}

In 1940, it was demonstrated that free DNA could be identified in the bloodstream. It was later shown that circulating nucleic acids (CNA), both DNA and RNA, are present in several neoplastic and non-neoplastic diseases, and that in cancer they originate mostly from the tumor. In this review, we discuss the potential application of CNA as a breast cancer biomarker for early diagnosis and patient evaluation. Most of the initial studies on CNA compared the levels of CNA in cancer patients and healthy individuals. To increase sensitivity and specificity, cancer-specific molecular alterations were then utilized. In this respect, epigenetic alterations and microRNA offer considerable advantages over mutations because of their easiness of detection. Epigenetic signatures, being early events of carcinogenesis, may also be valuable markers for screening purposes. Monitoring the follow-up of the patients is one of the most interesting applications of CNA-based assays, and it is reasonable to hypothesize that CNA may become a surrogate marker for circulating cancer cells in the prediction of patient outcome. Transferring these findings to the clinical practice is the next effort, and this will be possible when a 'common language' is defined to allow proper validation of these new markers.

\author{
Schlüsselwörter \\ Brustkrebs · Biomarker · Molekularbiologie . \\ Zirkulierende Nukleinsäuren
}

\section{Zusammenfassung}

Im Jahr 1940 wurde entdeckt, dass freie DNA im Blut nachweisbar ist. Später wurde gezeigt, dass zirkulierende Nukleinsäuren (CNA) - sowohl DNA als auch RNA - bei verschiedenen neoplastischen und nicht neoplastischen Erkrankungen vorkommen und dass sie bei Krebserkrankungen hauptsächlich aus dem Tumor stammen. In dieser Übersichtsarbeit diskutieren wir potentielle Anwendungsmöglichkeiten von CNA als Brustkrebsbiomarker für die Früherkennung und Einschätzung von $\mathrm{Pa}$ tienten. Die meisten frühen Studien zu CNA verglichen den CNA-Spiegel von Krebspatienten mit dem von gesunden Personen. Um die Sensitivität und Spezifität zu erhöhen, wurden schließlich krebsspezifische molekulare Veränderungen nutzbar gemacht. Diesbezüglich bieten epigenetische Veränderungen und microRNA auf Grund ihrer guten Nachweisbarkeit große Vorteile gegenüber Mutationen. Epigenetische Signaturen als frühe Ereignisse in der Karzinogenese könnten ebenfalls wichtige Marker für Screening-Zwecke sein. Das Follow-up von Patienten ist eine der interessantesten Anwendungsgebiete von CNA-basierten Assays, und man kann durchaus annehmen, dass CNA ein Ersatzmarker für zirkulierende Krebszellen zur Vorhersage des Patienten-Outcomes werden könnten. Die Überführung dieser Ergebnisse in die klinische Praxis stellt die nächste Hürde dar, und wird mit der Definition einer gemeinsamen «Sprache" zur korrekten Validierung dieser neuen Marker möglich werden.

\begin{tabular}{ll}
\hline KARGER & ( ) 2010 S. Karger GmbH, Freiburg \\
Fax +497614520714 & Accessible online at: \\
Information@Karger.de & www.karger.com/brc \\
www.karger.com &
\end{tabular}




\section{Introduction}

The existence of circulating DNA in the bloodstream of healthy individuals was observed for the first time in 1940 but the significance of this finding was not understood [1]. Since then, more than 30 years have elapsed before this neglected finding was rediscovered, first in auto-immune disorders [2], and later in cancer [3]. The potential relevance of circulating DNA in cancer was fully recognized in 1994 when identical mutations of the K-RAS gene were detected in the DNA extracted from pancreatic cancer tissues and from the serum of the corresponding patients [4]. It was later demonstrated that also tumor-derived mRNA could be isolated from bodily fluids [5]. This suggested that circulating DNA and RNA, collectively defined as circulating nucleic acids (CNA), could be clinically relevant biomarkers in several diseases. An important step toward the clinical utilization of CNA was set by the discovery, in 2003 , that $78 \%$ of lung cancer patients had significantly higher levels of CNA compared to healthy individuals [6]. This finding and the earlier, and almost unnoticed, observation that the level of CNA in cancer decreases after chemotherapy [3], could be taken as evidences supporting the utilization of CNA as cancer biomarkers and for screening purposes. Although the literature on CNA is vast, the possible utilization of this marker in the clinical setting is still debated and, to date, the evaluation of CNA is not yet endorsed in any clinical guideline. In this review, we summarize some of the findings on CNA in tumors, their relevance in breast cancer, and their potential utilization as diagnostic and prognostic markers.

\section{Origin of Circulating Nucleic Acids}

Several possible explanations for the release of nucleic acids into the bloodstream or, more generally, into bodily fluids have been proposed. A possible explanation for the origin of CNA is the presence of circulating tumor cells in the bloodstream [7]; this hypothesis was dismissed when the accurate quantification of DNA revealed that the amount of nucleic acids is in large excess compared to the number of circulating cancer cells [8].

\section{Circulating DNA}

In healthy individuals, small amounts of free DNA can be found in plasma [9]: it is believed that apoptosis is the primary source of this CNA supported by the fact that separation of normal plasma DNA by gel electrophoresis exhibits bands with a length equivalent to 185-200 bps or to a multiple of this number. This size corresponds with the internucleosomal cleavage of chromatin [10], which is a hallmark of apoptotic cell death. Increased levels of circulating DNA have been reported in the serum and plasma of patients with a variety of illnesses, including autoimmune disease, chronic inflammation, exhaustive exercise, or trauma and cancer [2, 3, 9, 11-14]. Evidence demonstrating the existence of high levels of DNA in plasma/serum of cancer patients is steadily increasing although the mechanism of nucleic acid release is uncertain. In cancer patients, the amount of DNA in serum is approximately 4 times that of healthy controls [9]. Importantly, unlike the uniformly truncated DNA released from apoptotic cells, the size of the DNA released from dead cancer cells largely varies in size and, on average, is longer than that of non-neoplastic DNA released by apoptosis $[15,16]$. The integrity of circulating DNA, measured as the ratio of longer to shorter DNA fragments, is higher in patients with gynecologic and breast cancers than in normal individuals and has been proposed as a clinical marker for breast cancer progression [17].

\section{Circulating RNA}

Although RNA is a very labile molecule, the presence of tumor-derived tyrosinase mRNA in the bloodstream of 6 melanoma patients was detected in 1999, and later it was demonstrated that mRNA binds to small particles that protect it from ribonuclease degradation [5, 18]. The presence of mRNA in bodily fluids opens the possibility of performing profiling expression studies from CNA.

\section{CNA Extraction and Analysis: Problems and Solutions}

The early studies on CNA were made difficult by the small amount of DNA present in bodily fluids. The widespread utilization of polymerase chain reaction (PCR) and, importantly, of quantitative PCR (qPCR) methods of analysis, has allowed to recognize CNA as an important potential biomarker. CNA can be extracted from all bodily fluids but blood is the most widely utilized source of CNA.

There is no valid solution to the problem as to whether serum or plasma is the best substrate for the analysis of cellfree nucleic acids. The yield from plasma is lower then that from serum, probably because clotting can release CNA from white blood cells. This 'normal' contamination is obviously undesirable for the correct quantification of CNA or for mutation detection. The ratio between long and short DNA fragments [17] can be utilized to estimate the extent of non-tumor DNA contamination in the sample.

Various methods have been used to purify CNA, almost as numerous as the laboratories working on CNA. No agreed standards on their extraction and purification exist till now, also because many publications fail to specify how samples were obtained, processed, and analyzed. The methods mostly utilized are based on ion-exchange resins, salting-out and magnetic beads separation. Several commercial kits designed for nucleic acid extraction from bodily fluids are available. Recently, a new protocol based on the treatment with Triton $\mathrm{X}$, heat, and phenol (THP) was introduced for DNA extraction [19] and seems to combine good recovery with low cost. 
Pre-analytical factors, like delay in blood processing, clotting, freezing-thawing, and storage temperature, have a strong influence on yield and integrity of circulating cell-free DNA [20]. In our laboratory, blood samples stabilized on EDTAcontaining tubes are maintained at $4{ }^{\circ} \mathrm{C}$ and processed within $6 \mathrm{~h}$ after collection. Plasma is separated from the blood cells by centrifugation at $1,600 \times \mathrm{g}$ for $10 \mathrm{~min}$ and then at $16,000 \times \mathrm{g}$ for $10 \mathrm{~min}$ to ensure the complete removal of cells, and stored at $-80{ }^{\circ} \mathrm{C}$ until extraction. The problem of prolonged sample storage has been highlighted by a recent report showing that DNA levels in plasma stored at $-80{ }^{\circ} \mathrm{C}$ declines by $30 \%$ per year [21]. With the introduction of PCR, picogram quantities of DNA could be detected and real-time qPCR further increases the sensitivity of CNA analysis: for this reason effective anti-contamination measures should be strictly followed.

Quantification of total DNA was originally performed using dye-binding assays, but real-time qPCR methods based on a continuous monitoring of fluorescence by an optical system are now considered the gold standard. Although the sensitivity of the PCR-based technologies is very high, the yield of CNA from bodily fluids is generally very low and, as a consequence, the number of assays that can be performed is limited. Depending upon the type of molecular lesions investigated, multiple assays should be performed to detect the disease-relevant lesion; therefore, methods to homogeneously amplify the minimal amounts of DNA must be employed before analytical PCR assays [22]. As we will see in a later section of this review, aberrant DNA methylation is a promising cancer biomarker. To maintain the methylation signatures and to increase the amount of available DNA, another assay that couples bisulfite DNA modification (to 'fix' the methylation status) and DNA amplification was developed [23]. Commercial kits to perform these tasks are now available.

\section{Circulating DNA Quantification as a Genomic Test for Cancer: Lights and Shadows}

The usefulness of a cancer biomarker is given by its sensitivity and specificity. At the laboratory stage, sensitivity is defined as the minimal amount of a given target that can be detected by the assay (i.e. the minimal amount of mutated DNA that can be detected) whereas the specificity is the minimal amount of a specific target, for example a mutation, that can be detected in the presence of an excess of non-mutated DNA in the biological sample. Sensitivity and specificity are of particular importance during the development of a biomarker and, ideally, an assay should detect $100 \%$ of the cases in a test group whereas none of the controls should result positive. In this respect, many studies considered only the level of circulating DNA, and demonstrated a statistically significant higher level of DNA in a variable percentage of cases as compared to the controls. Although these studies are promising, there are 'lights and shadows' that make debatable the quantification of circulating DNA as a cancer assay. In a comprehensive review where the results of multiple studies were compared [24], the reported amount of DNA in the bloodstream of breast cancer patients varies from 153 to $549 \mathrm{ng} / \mathrm{ml}$ in serum and from 122 to $462 \mathrm{ng} / \mathrm{ml}$ in plasma whereas that of healthy controls was between 63-318 and 3-63 ng/ml, respectively. The first conclusion that can be drawn is that the specificity of quantification of DNA in plasma is higher than that from serum. Nevertheless, further tests are necessary to establish the usefulness of this type of analysis since large individual variations in DNA quantity were observed among different studies. Furthermore, essentially nothing is known about the physiological fluctuations of CNA content. In this respect, it was demonstrated that exercise can dramatically but transiently increase the amount of cell-free DNA in plasma of healthy individuals [13]. In breast cancer, the level of circulating DNA decreases after surgery [25]; prospective studies will be necessary to determine if monitoring the circulating DNA levels during and after therapy can predict the clinical response.

An analytical approach to DNA quantification as a clinical biomarker was recently conducted by coupling qPCR with Receiver Operating Characteristic (ROC) curve analysis utilizing as a target circulating nuclear and mitochondrial DNA [26]. The data presented showed that this quantitative approach could distinguish between cancer patients and healthy controls with a sensitivity and specificity of 81 and $69 \%$ utilizing nuclear DNA. Substantially lower sensitivity (53\%) but increased specificity (87\%) was seen with mitochondrial DNA.

CNA quantification has stronger potential applications as a prognostic factor and to monitor disease progression and response to therapy. In this respect, it was mentioned earlier [17] that the integrity of circulating DNA measured by ALUqPCR in breast cancer is significantly linked to AJCC stage, tumor size, and nodal metastases. Importantly, also in patients with micrometastatic spreading, DNA integrity was higher than in healthy females. Overall, this assay may have a clinical utility although this should be verified in multicentric studies.

\section{Genetic and Epigenetic Alterations in Circulating DNA: Steps Toward Clinical Application}

In the recent years, most of the studies were directed toward the identification of cancer-specific molecular alterations in circulating DNA. This approach originates from the wellknown concept that cancer cells harbor a variety of genetic alterations. Thus, if CNA originate from the tumor, it is conceivable that the same set of abnormalities is present in cancer cells and in circulating DNA. Indeed, a large number of reports confirmed the first observation demonstrating that the same molecular alteration can be detected in the tumor and in the CNA of the patients [4]. Importantly, in a longitudinal prospective study, cancer-associated mutations were found in circulating DNA of individuals exposed to carcinogens and 
Table 1. TP53 point mutations in breast cancer (exons 5-8)

\begin{tabular}{llll}
\hline $\begin{array}{l}\text { Mutations in tumor, } \\
\text { n } \%)\end{array}$ & $\begin{array}{l}\text { Mutations in } \\
\text { plasma/serum, n (\%) }\end{array}$ & Clinical correlation & Ref. \\
\hline $46 / 126(36)$ & $30 / 126(24)$ & clinical stage and recurrence $^{\text {a }}$ & {$[28]$} \\
$7 / 62(11)$ & $3 / 62(5)$ & yes $^{\mathrm{a}}$ & {$[29]$} \\
$7 / 41(17)$ & $2 / 41(5)$ & yes $^{\mathrm{a}}$ & {$[30]$} \\
$104 / 142(73)$ & $61 / 142(43)$ & $\mathrm{yes}^{\mathrm{a}}$ & {$[31]$} \\
Total 164/371 (44) & Total 96/371 (26) & & \\
\hline
\end{tabular}

${ }^{\mathrm{a}}$ Clinical correlation included several different molecular markers and not only p53 mutations.

were associated with an increased risk of cancer development [27]. Almost all types of DNA alterations studied in tumors were also analyzed, and rearrangements and mitochondrial DNA mutations were all detected [24]. In breast cancer, the most common mutations considered were those in exons 5-8 of TP53 (codons 126-306), thus within the mutation hot-spot region of this gene.

The results of the mutational analysis of 4 studies [28-31] that included a total of 371 patients are summarized in table 1. Overall, TP53 mutations could be detected in $44 \%$ of the tumors, but in circulating DNA this percentage dropped to $26 \%$. Importantly, huge variations were observed between the different cohorts $(11-73 \%$ and $5-43 \%$ for tumors and circulating DNA, respectively) as the likely consequence of the different sensitivity of the methodologies utilized (PCR/single strand conformation polymorphism (SSCP), SSCP alone or $\mathrm{PCR} / \mathrm{SSCP} /$ sequencing). Although the sensitivity of the detection of TP53 mutation appears modest, 3 of these studies [2931] considered also other molecular characteristics in the analysis (mainly multiple microsatellite polymorphisms) and showed that also these alterations could be identified in DNA from tumors and from the plasma or serum of the patients.

Microsatellite and variable number of tandem repeats (VNTR) are highly polymorphic and evenly distributed sequences consisting in the repetition of 1-40 nucleotides generally outside the coding regions. Polymorphism analysis can reveal allelic imbalances (AI) and loss of heterozygosis ( $\mathrm{LOH})$, and was utilized to determine the clonal origin of breast cancer [32]. The first evidence of microsatellite alterations in plasma DNA of cancer patients dates back to 1996 [33], and since then a large number of reports confirmed that original observation. Microsatellite alterations in breast cancer are found more commonly than TP53 mutations (reviewed in [24]). In these studies, multiple loci were analyzed, and, similarly to TP53 mutations, the percentage of tumors and circulating DNA with at least one alteration varies widely depending upon the locus taken into consideration. Nevertheless, the multiplicity of the targets makes microsatellite analysis more informative than TP53 mutations search. Importantly, AI or LOH were not observed in any of the healthy subjects whereas they were detectable in patients with carcinoma in situ [8] suggesting the potential application of this type of analysis in screening proce- dures. However, as it will be discussed later, efforts should be made to increase the sensitivity of this test. The association between $\mathrm{AI}$ or $\mathrm{LOH}$ and the clinical characteristics of the patients could not be firmly established in most of the studies. It is likely that the definition of a panel of informative microsatellites could help to understand the clinical meaning of these alterations. In recent years, it was recognized that epigenetic changes are a constant alteration in cancer cells occurring early in carcinogenesis (recent review in [34]. Assaying the methylation status has several advantages over mutation or microsatellite analysis. Indeed, methylation is a stable modification easily detected by simple PCR procedures, and multiple assays on a panel of genes can be conducted with as little as $0.5 \mathrm{ml}$ of serum [23].

Importantly, different tumors present distinct patterns of gene hypermethylation, and, in principle, this could lead to the identification of panels of target sequences to increase the specificity and sensitivity of the assay. In breast cancer, several genes were found hypermethylated at early stages of the disease. Utilizing a small set of genes (APC, RASSF1A, DAP kinase), hypermethylation of at least one of them was shown in $94 \%$ of the 34 patients included in the study and in $76 \%$ of the corresponding circulating DNA [35].

The non-invasive detection of preneoplastic or minimal lesions in breast is of the utmost importance. In this respect, an increased risk of breast cancer has been documented in patients with fibroadenoma, and the presence of tumor-associated lesions in benign tumors has been documented $[8,36$, 37]. Interestingly, tumor-associated alterations were detected in the serum of patients with in situ carcinoma and with benign breast disease suggesting that this approach might have a supporting role in the early diagnosis of breast cancer $[35,37,38]$.

Most of the studies on the role of methylation in cancer were conducted in tumor tissues or serum utilizing qualitative techniques generating dichotomous data (methylated or unmethylated). However, since methylation can be more faithfully represented as a continuous variable, it is likely that quantitative methodologies might define threshold levels of methylation capable of discriminating tumors with different behaviors as it was recently demonstrated for a childhood tumor [32]. 


\section{Circulating RNA}

The demonstration of tumor-derived RNA transcripts in plasma provides new targets for cancer detection. In breast cancer, the targets analyzed were hTR, hTERT, mammaglobin, CK19 [39-41], and, more recently, some MiRNA. Telomerase mRNA was the first RNA target to be analyzed in breast cancer and was found expressed in $25-28 \%$ of the patients and in none of the healthy subjects or in patients with benign breast disease [39]. In 2 independent studies, mammaglobin mRNA was frequently detected $(60 \%)$ in patients. Unfortunately, also a substantial percentage of unaffected women were positive (12-38\%) [40, 41]. Similarly, CK19 mRNA was detected in healthy individuals (20\%) and breast cancer patients (49\%) [41]. Circulating MiRNA are a recent addition to the set of potential CNA biomarkers. These small molecules have the potential of becoming very useful cancer markers since their expression profile is aberrant and highly specific in cancer. Furthermore, they are highly stable and can be easily quantified by a large number of pre-designed kits. Although MiRNA are likely to become important biomarkers in breast cancer (reviewed in [42]), only few studies so far have addressed their differential presence in bodily fluids of breast cancer patients.

\section{CNA Analysis in the Follow-Up of Breast Cancer Patients}

CNA levels in breast cancer patients are higher than in healthy women. Interestingly, CNA levels significantly decrease after tumor resection and tend to decrease during follow-up [25, 43] suggesting that CNA analysis may be a very promising tool to monitor the patient's response to adjuvant therapy. The strong potential clinical impact of CNA analysis is suggested by a retrospective study where the presence of methylated RASSF1A gene promoter sequences in the serum of 148 breast cancer patients was determined at diagnosis, after surgery, and during follow-up [44]. This study clearly showed that the patients that were positive for methylated RASSF1A sequences at diagnosis and that became negative after initial treatment (an indicator of response to treatment) had a much better outcome than the patients that reversed from negative to positive during treatment (an indicator of disease progression). This finding was recently confirmed utilizing two other genes: $14.3 .3 \sigma$ and ESR1 [38]. Although the analysis of the methylation status of informative target sequences to monitor the efficacy of the therapy is still in its developmental stage, it is reasonable to hypothesize that a panel of methylated targets might be utilized as surrogate marker for circulating breast cancer cells. Prospective comparative studies will be necessary to determine specificity and sensitivity of the two assays.

\section{Conclusions}

Improvements in analytical techniques have allowed the analysis of minute and partially degraded nucleic acid fragments. This and the recognition of non-cellular DNA and RNA in the bodily fluids of patients and healthy individuals have opened new and exciting possibilities for advanced non-invasive diagnostic procedures. Nevertheless, even if statistically significant differences were reported between cases and controls in a variety of studies, the transfer of these exciting results into clinical practice still requires proper validation. In particular, a major effort should be the definition of common procedures, standards, and controls to change interesting laboratory findings into clinically relevant procedures for the benefit of the patients.

\section{Acknowledgements}

This work was supported by the Italian Health Ministry Grants: Integrated Project 'Validazione clinica e analitica di markers biomolecolari di diagnosi oncologica su materiale biologico ottenuto con tecniche non invasive' and 'Progetto Oncologico di Medicina Molecolare: Tumori Femminili'

\section{Conflict of Interest}

None of the authors has any conflict of interest that could have biased the work.

\section{References}

1 Mandel PM: Les acides nucleiques du plasma sanguin chez l'homme. CR Acad Sci Paris 1940;142: 241-253.

- Tan EM, Schur PH, Carr RI, Kunkel HG: Deoxybonucleic acid (DNA) and antibodies to DNA in the serum of patients with systemic lupus erythematosus. J Clin Invest 1966:45:1732-1740.

3 Leon SA, Shapiro B, Sklaroff DM, Yaros MJ: Free DNA in the serum of cancer patients and the effect of therapy. Cancer Res 1977;37:646-650.
4 Sorenson GD, Pribish DM, Valone FH, Memoli VA, Bzik DJ, Yao SL: Soluble normal and mutated DNA sequences from single-copy genes in human blood. Cancer Epidemiol Biomarkers Prev 1994; 3:67-71.

5 Kopreski MS, Benko FA, Kwak LW, Gocke CD: Detection of tumor messenger RNA in the serum of patients with malignant melanoma. Clin Cancer Res 1999:5:1961-1965.
6 Sozzi G, Conte D, Leon M, Ciricione R, Roz L, Ratcliffe C, Roz E, Cirenei N, Bellomi M, Pelosi G, Pierotti MA, Pastorino U: Quantification of free circulating DNA as a diagnostic marker in lung cancer. J Clin Oncol 2003;21:3902-3908.

7 Yam LT, Janckila AJ: Immunocytodiagnosis of carcinocythemia in disseminated breast cancer. Acta Cytol 1987;31:68-72. 
$>_{8}$ Chen X, Bonnefoi H, Diebold-Berger S, Lyautey J, Lederrey C, Faltin-Traub E, Stroun M, Anker P: Detecting tumor-related alterations in plasma or serum DNA of patients diagnosed with breast cancer. Clin Cancer Res 1999;5:2297-2303.

$\checkmark 9$ Shapiro B, Chakrabarty M, Cohn EM, Leon SA: Determination of circulating DNA levels in patients with benign or malignant gastrointestinal disease. Cancer 1983;51:2116-2120.

10 Giacona MB, Ruben GC, Iczkowski KA, Roos TB, Porter DM, Sorenson GD: Cell-free DNA in human blood plasma: Length measurements in patients with pancreatic cancer and healthy controls. Pancreas 1998;17:89-97.

11 Koffler D, Agnello V, Winchester R, Kunkel HG: The occurrence of single-stranded DNA in the serum of patients with systemic lupus erythematosus and other diseases. J Clin Invest 1973;52:198-204.

$\checkmark 12$ Leon SA, Revach M, Ehrlich GE, Adler R, Petersen V, Shapiro B: DNA in synovial fluid and the circulation of patients with arthritis. Arthritis Rheum 1981;24:1142-1150.

13 Atamaniuk J, Vidotto C, Tschan H, Bachl N, Stuhlmeier KM, Muller MM: Increased concentrations of cell-free plasma DNA after exhaustive exercise. Clin Chem 2004;50:1668-1670.

14 Lo YM, Rainer TH, Chan LY, Hjelm NM, Cocks RA: Plasma DNA as a prognostic marker in trauma patients. Clin Chem 2000;46:319-323.

15 Swarup V, Rajeswari MR: Circulating (cell-free) nucleic acids--a promising, non-invasive tool for early detection of several human diseases. FEBS Lett 2007;581:795-799.

16 Hodgson DR, Wellings R, Orr MC, McCormack R, Malone M, Board RE, Cantarini MV: Circulating tumour-derived predictive biomarkers in oncology. Drug Discov Today 2010;15:98-101.

17 Umetani N, Giuliano AE, Hiramatsu SH, Amersi F, Nakagawa T, Martino S, Hoon DS: Prediction of breast tumor progression by integrity of free circulating DNA in serum. J Clin Oncol 2006;24: 4270-4276.

18 Ng EK, Tsui NB, Lam NY, Chiu RW, Yu SC, Wong SC, Lo ES, Rainer TH, Johnson PJ, Lo YM: Presence of filterable and nonfilterable mRNA in the plasma of cancer patients and healthy individuals. Clin Chem 2002;48:1212-1217.

19 Xue X, Teare MD, Holen I, Zhu YM, Woll PJ: Optimizing the yield and utility of circulating cellfree DNA from plasma and serum. Clin Chim Acta 2009;404:100-104

20 Chan KC, Yeung SW, Lui WB, Rainer TH, Lo YM Effects of preanalytical factors on the molecular size of cell-free DNA in blood. Clin Chem 2005;51: 781-784.

-21 Sozzi G, Roz L, Conte D, Mariani L, Andriani F, Verderio P, Pastorino U: Effects of prolonged storage of whole plasma or isolated plasma DNA on the results of circulating DNA quantification assays. J Natl Cancer Inst 2005;97:1848-1850.
22 Telenius H, Carter NP, Bebb CE, Nordenskjold M, Ponder BA, Tunnacliffe A: Degenerate oligonucleotide-primed PCR: general amplification of target DNA by a single degenerate primer. Genomics 1992;13:718-725.

23 Di Vinci A, Gelvi I, Banelli B, Casciano I, Allemanni G, Romani M: Meth-DOP-PCR: an assay for the methylation profiling of trace amounts of DNA extracted from bodily fluids. Lab Invest 2006; 86:297-303.

24 Fleischhacker M, Schmidt B: Circulating nucleic acids (CANs) and cancer - a survey. Biochim Biophys Acta 2007;1775:181-232.

25 Catarino R, Ferreira MM, Rodrigues H, Coelho A, Nogal A, Sousa A, Medeiros R: Quantification of free circulating tumor DNA as a diagnostic marker for breast cancer. DNA Cell Biol 2008;27:415-421.

26 Kohler C, Radpour R, Barekati Z, Asadollahi R, Bitzer J, Wight E, Burki N, Diesch C, Holzgreve W, Zhong XY: Levels of plasma circulating cell free nuclear and mitochondrial DNA as potential biomarkers for breast tumors. Mol Cancer 2009;8:105. 27 Gormally E, Vineis P, Matullo G, Veglia F, Caboux E, Le Roux E, Peluso M, Garte S, Guarrera S, Munnia A, Airoldi L, Autrup H, Malaveille C, Dunning A, Overvad K, Tjonneland A, Lund E, Clavel-Chapelon F, Boeing H, Trichopoulou A, Palli D, Krogh V, Tumino R, Panico S, Buenode-Mesquita HB, Peeters PH, Pera G, Martinez C, Dorronsoro M, Barricarte A, Navarro C, Quiros JR, Hallmans G, Day NE, Key TJ, Saracci R, Kaaks R, Riboli E, Hainaut P: Tp53 and kras2 mutations in plasma DNA of healthy subjects and subsequent cancer occurrence: a prospective study. Cancer Res 2006;66:6871-6876.

28 Di GH, Liu G, Wu J, Shen ZZ, Shao ZM: (Peripheral blood mutated p53 DNA and its clinical value in human breast cancer). Zhonghua Zhong Liu Za Zhi 2003;25:137-140.

29 Silva JM, Dominguez G, Garcia JM, Gonzalez R, Villanueva MJ, Navarro F, Provencio M, San Martin S, Espana P, Bonilla F: Presence of tumor DNA in plasma of breast cancer patients: clinicopathological correlations. Cancer Res 1999;59:3251-3256.

30 Silva JM, Garcia JM, Dominguez G, Silva J, Miralles $\mathrm{C}$, Cantos $\mathrm{B}$, Coca $\mathrm{S}$, Provencio $\mathrm{M}$, Espana $\mathrm{P}$, Bonilla F: Persistence of tumor DNA in plasma of breast cancer patients after mastectomy. Ann Surg Oncol 2002;9:71-76.

31 Garcia JM, Garcia V, Silva J, Pena C, Dominguez G, Sanchez A, Sanfrutos L, Provencio M, Millan I, Chaparro D, Espana P, Bonilla F: Extracellular tumor DNA in plasma and overall survival in breast cancer patients. Genes Chromosomes Cancer 2006;45:692-701.

32 Banelli B, Casciano I, Di Vinci A, Gatteschi B, Levaggi A, Carli F, Bighin C, Salvi S, Allemanni G, Ghiorzo P, Pronzato P, Venturini M, Romani M, Del Mastro L: Pathological and molecular characteristics distinguishing contralateral metastatic from new primary breast cancer. Ann Oncol 2009; Epub ahead of print.
33 Chen XQ, Stroun M, Magnenat JL, Nicod LP, Kurt AM, Lyautey J, Lederrey C, Anker P: Microsatellite alterations in plasma DNA of small cell lung cancer patients. Nat Med 1996;2:1033-1035.

34 Dehan P, Kustermans G, Guenin S, Horion J, Boniver J, Delvenne P: DNA methylation and cancer diagnosis: New methods and applications. Expert Rev Mol Diagn 2009;9:651-657.

35 Dulaimi E, Hillinck J, Ibanez de Caceres I, AlSaleem T, Cairns P: Tumor suppressor gene promoter hypermethylation in serum of breast cancer patients. Clin Cancer Res 2004;10:6189-6193.

36 Di Vinci A, Perdelli L, Banelli B, Salvi S, Casciano I, Gelvi I, Allemanni G, Margallo E, Gatteschi B, Romani M: P16(ink4a) promoter methylation and protein expression in breast fibroadenoma and carcinoma. Int J Cancer 2005;114:414-421.

37 McCulloch RK, Sellner LN, Papadimitrou JM, Turbett GR: The incidence of microsatellite instability and loss of heterozygosity in fibroadenoma of the breast. Breast Cancer Res Treat 1998;49:165-169.

38 Martinez-Galan J, Torres B, Del Moral R, MunozGamez JA, Martin-Oliva D, Villalobos M, Nunez MI, Luna Jde D, Oliver FJ, Ruiz de Almodovar JM: Quantitative detection of methylated ESR1 and 14-3-3-sigma gene promoters in serum as candidate biomarkers for diagnosis of breast cancer and evaluation of treatment efficacy. Cancer Biol Ther 2008;7:958-965.

39 Chen XQ, Bonnefoi H, Pelte MF, Lyautey J, Lederrey C, Movarekhi S, Schaeffer P, Mulcahy HE, Meyer P, Stroun M, Anker P: Telomerase RNA as a detection marker in the serum of breast cancer patients. Clin Cancer Res 2000;6:3823-3826.

40 Gal S, Fidler C, Lo YM, Chin K, Moore J, Harris AL, Wainscoat JS: Detection of mammaglobin mRNA in the plasma of breast cancer patients. Ann N Y Acad Sci 2001;945:192-194.

41 Silva JM, Dominguez G, Silva J, Garcia JM, Sanchez A, Rodriguez O, Provencio M, Espana P, Bonilla F: Detection of epithelial messenger RNA in the plasma of breast cancer patients is associated with poor prognosis tumor characteristics. Clin Cancer Res 2001;7:2821-2825.

42 Heneghan HM, Miller, N., Lowery, A.J., Sweeney, K.J., Kerin, M.J.: MicroRNAs as novel biomarkers for breast cancer. J Oncol 2009; Epub ahead of print

43 Huang ZH, Li LH, Hua D: Quantitative analysis of plasma circulating DNA at diagnosis and during follow-up of breast cancer patients. Cancer Lett 2006;243:64-70

44 Fiegl H, Millinger S, Mueller-Holzner E, Marth C, Ensinger C, Berger A, Klocker H, Goebel G, Widschwendter M: Circulating tumor-specific DNA: a marker for monitoring efficacy of adjuvant therapy in cancer patients. Cancer Res 2005;65: 1141-1145. 